\title{
Towards Cost Effective Data Centers
}

\author{
Ajay Ahuja \\ Indian Institute of Technology, New Delhi \\ Vinayshil Gautam, \\ Indian Institute of Technology, New Delhi
}

\begin{abstract}
Data Centers are sub organizations within an IT organization and form an integral part of e-enabled services infrastructure. Their effectiveness is essential for effectiveness of overall IT organization leading to efficient and effective delivery of e-services. Data Center organizations aim for Organizational Effectiveness. Many factors and measures can contribute to Organizational Effectiveness of Data Centers. This paper presents some of the findings from a research study on "Select aspects of Organizational Effectiveness of Data Centers". As an outcome of this study, amongst other measures, Total Cost of Ownership (TCO) was derived as a critical measure for effective Data Centers. Lower TCO leads to cost effective Data Centers, leading to overall effectiveness. In this paper, we briefly introduce various measures of Data Centers' Organizational Effectiveness and present a detailed analysis of Total Cost of Ownership (TCO) as a key measure of Data Centers' Organizational Effectiveness. We also present various factors contributing to reduced TCO and a comparison between the factors contributing to TCO for Government and Corporate Data Centers.
\end{abstract}

Key Words: Data Centers, Organizational Effectiveness, Total Cost of Ownership (TCO).

\section{INTRODUCTION}

$\Lambda$

11 of us are associated with one organization or another, in one form or another - the association spans from personal to professional front. A typical organization has a structure and processes to follow and an overall goal or objective to achieve. The structure, processes and skills of people varies from one organization to another and is ever evolving, based on the distinct goals and objectives. In today's IT enabled e-world, Information Technology (IT) has become integral part of organization's existence. IT technologies enabled with virtualization and networking are enabling newer forms of organizations. e-enabled services are being introduced and widely accepted. This is equally true for Government organizations, who are aiming for good governance through e-enabled services.

These e-enabled services are further enabled by underlying IT infrastructure, which is hosted in back-end Data Centers. These Data Centers are modernized forms of erstwhile server rooms which used to host traditional IT infrastructure. Today's Data Centers host servers, storage, networking, databases, applications, other IT related equipment and the actual data itself -

Journal of Technology

Management for Growing Economies

Vol. 3 No. 2

October 2012 pp. $105-117$

\section{CHITKARA 司} UNIVERSITY

(C)2012 by Chitkara University. All Rights Reserved. 
Ahuja, A.

Gautam, V.

which is required to e-enable services.

Data Centers are also organizations in themselves. They also have a structure, processes and people to execute these processes with an overall aim or goal to host or enable e-Services. Just like for any other organization, Data Center organizations also aim for effectiveness - Organizational Effectiveness is critical to Data Centers. Organizational Effectiveness has been studied for various domains and for various organizations in different domains, but there is very limited information available on Organizational Effectiveness of Data Centers.

This paper presents the findings of one such research study on Organizational Effectiveness of Data Centers, with a specific focus on Total Cost of Ownership (TCO), as a key determinant of effectiveness. Various factors related to TCO have also been discussed and presented in this paper.

\section{THEORETICAL BACKGROUND AND NEED FOR STUDY}

Organizations and organizational effectiveness has been studied over many years by researchers and management gurus. Organization concepts and forms have dynamically evolved over time; Hybrid forms of organization have evolved, which are rightly suited for transactions that require a mix of incentives, adaptation and control (Williamson, 1991). Technology and connectivity is further contributing to newer forms. Today we are also talking of virtual and networked organizations. Networked organizations have received much attention (Thorelli 1986, Powell, 1987).

Organizational Effectiveness is essential to any organization. Organizational effectiveness has been related to various measures and factors. Lewin and Minton (1986) collated and summarized various definitions of Organizational Effectiveness. Amongst many factors, this summary (as cited from their work) related Organizational Effectiveness to product maximization, cost minimization, optimal resource utilization and task specialization (Taylor, 1911), division of work (Fayol, 1925), employee satisfaction (Mayo, 1933), structure strategy congruence (Chandler, 1962), efficiency through economy of scales (Sloan, 1963) etc.

Organizational Effectiveness has also been related to multiple stakeholder satisfaction (Beer et. al, 1995) and to the ability to transform inputs to desired outputs in achieving organizational goals (Gautam \& Batra, 2007) in an optimal manner.

Cost control has also become a major focal point in managing organizations. Wilson (1983) states that whole of the organization and its needs should be seen as the context within which cost control takes place. Cost is synonymous with sacrifice, but its precise definition depends on the 
situation in which a measure of sacrifice is required, different cost concepts are relevant to different sets of circumstances. Organizational Effectiveness has been related to lower costs and higher profits. Cost reduction is important to all - be-it-be a housewife, an individual manager, an industrial organization or the Government (Gopalakrishnan, 1992). Total Cost of Ownership, which spans across various situations, in an organization may be a right measure for effectiveness.

Determinants of Organizational Effectiveness may vary from one organization to another or from one domain to another, but Organizational Effectiveness is critical to the existence of any organization and its importance cannot be ignored (Cameron, 1986).

Data Centers are also organizations with a specific structure, set of processes and a group of people who manage and operate within this process framework. Concepts of networked, virtualized and hybrid organizations are applicable to Data Center organizations. Organizational Effectiveness is also applicable to Data Center organizations.

With the advancement is e-enabled services, Data Centers are gaining importance. The IT infrastructure to host these services is hosted within these Data Centers, it is absolutely essential to have state-of-the-art highly efficient and highly effective Data Centers.

Indian Government's Department of Information Technology is promoting and guiding various states across the country, to setup and design State Data Centers to host Citizen Services. Some of these SDCs are already in operation and are further looking at expansion options. Dynamic reference architectures for the State Data Centers (SDC's) have been proposed by various researchers. These dynamically changeable architectures can be adopted by the states, allowing them change (grow or shrink) with the change in IT application requirements. There have been discussions and recommendations for a sample Data Center configuration based on a reliable, highly available, scalable, secure, space and power efficient cost effective design. (Ahuja, 2006). Such a design forms a foundation of an effective Data Center.

There are many studies on Organizational Effectiveness for variety of domains - but there is very limited information, in particular on Organizational Effectiveness of Data Centers. There are gaps, which need to be plugged-in. There is a need to study this universe of Data Centers and arrive at the defining measures and factors of Organizational Effectiveness. It is important to arrive at a model for Data Centers' Organizational Effectiveness.

In addition to other measures, Total Cost of Ownership (TCO) is also a crucial measure to judge effectiveness of Data Centers. With the ever increasing user demands, the cost to build and operate a modern Data Center continues to

Journal of Technology Management for Growing Economies, Volume 3, Number 2, October 2012
Towards Cost

Effective Data

Centers

107 
Ahuja, A.

Gautam, V.

108 increase. This Total Cost of Ownership (TCO) includes capital and operational expenses (Patterson et al., 2007).

Predicting and measuring Total Cost of Ownership (TCO) for the physical infrastructure for network rooms and Data Centers is required for Return-onInvestment (ROI) analysis and other business decision processes. The over sizing of infrastructure is major contributor to the TCO. Electricity, cooling, space, service, monitoring and management costs also contribute to the TCO (Rasmussen, 2005).

It is important to study the measures contributing to Organizational Effectiveness of Data Centers. This paper summarizes the findings of one such research study, with a specific focus on outcomes of Total Cost of Ownership as a key measure for Data Centers' Organizational Effectiveness.

\section{THE METHODOLOGY}

Due to limited availability of specific models or measures for Data Centers' Organizational Effectiveness, as a first step, a basic framework of measures of Organizational Effectiveness was created using findings from literature survey of Organizational Effectiveness studies in other domains. In addition to this, exploratory study of two of the renowned Data Centers in India was also carried out. This was primarily an exploratory, participative ethno-research study; with coverage of a major Government and a Corporate sector Data Center. The study involved "inquiry from inside" as opposed to "from outside" (Evered and Louis, 1981), collating inputs from various Data Center experts and focus group discussions. Information on operational excellence of Data Centers was also collected from various other secondary data sources. Based on these inputs, a base model on Organizational Effectiveness of Data Centers was arrived at.

This base model was further used to formulate propositions, which were then used to create a questionnaire and diary of observation. The questionnaire and diary of observation was used to collect data from sixty three different Data Center organizations in India. Data collected via questionnaire was also complemented by qualitative inputs from fifty six one-to-one interviews with key Data Center stakeholders.

Overall there were 145 questionnaire responses. Respondents were requested to relate Data Center Organizational Effectiveness to various measures, including the lower "Total Cost of Ownership (TCO)" construct, on a Likert Type scale of 1 to 5, 1 pointing to "strongly disagree" and 5 pointing to "strongly agree".

In addition to this, inputs were also collected from three national seminars and 7 expert panelists. Some of these seminars and all of the fifty six interviews

Journal of Technology Management for Growing Economies, Volume 3, Number 2, October 2012 
were video recorded. This helped us generate rich source of insightful data.

Qualitative and quantitative data was further analyzed using statistical analysis tools (WEFT for qualitative data and SPSS for quantitative data) to arrive at measures and corresponding factors contributing to Organizational Effectiveness of Data Centers.

Based on these findings, Data Center Organizational Effectiveness was related to following measures. Each of these measures was further related to various factors. These measures included:

- Employee satisfaction.

- Customer focused approach.

- Adaptability.

- Lower Total Cost of Ownership (TCO).

- Well-defined processes.

- Flexible organization structure.

- IT (server and storage) efficiency.

- Facilities efficiency (UPS, power, cooling).

Findings corresponding to all these measures and corresponding factors are available, as a part of the complete research report.

This paper however, summarizes the results specifically related to the lower TCO construct. Next section discusses the findings related to Total Cost of Ownership (TCO) as a measure of Data Centers' Organizational Effectiveness.

\section{TOTAL COST OF OWNERSHIP - A KEY MEASURE FOR COST EF- FECTIVE DATA CENTERS}

Based on the qualitative inputs from exploratory case studies, seminars, panel discussions and 56 one-to-one interviews and quantitative data from 145 questionnaires, lower TCO came up as a key measure of Data Centers' Organizational Effectiveness.

Further, factors related to lower TCO, were also explored and rated. The questionnaire had items corresponding to each of these factors. The factors are summarized below:

- Online serviceable IT equipment: Total Cost of Ownership (TCO) may be related to easy and online serviceability, leading to reduced service costs, further leading to lower TCO.

- Service Level Agreements (SLA's) with the power facility providers: To find the relevance of having well defined SLA's with power facility providers and its impact on TCO.

- Service Level Agreements (SLA's) with cooling facility providers: To find the relevance of having well-defined SLA's with cooling facility providers

Journal of Technology Management for Growing Economies, Volume 3, Number 2, October 2012 
Ahuja, A.

Gautam, V.

and its impact on TCO.

- Flexible power and cooling facility: To study the impact of flexible power and cooling facility infrastructure on the TCO.

- $\quad$ Rack mount equipment: To explore if usage of rack mount, equipment can lead to lower TCO, by saving on space and power.

- Trainings and updates: To evaluate if training and updates, which keeps the employees abreast with the changes, can help bring down TCO.

- Outsourcing IT infrastructure: To see if outsourcing IT can reduce TCO.

- Outsourcing facilities infrastructure: To see if outsourcing the facilities equipment can reduce TCO. Facilities infrastructure includes both the power and cooling infrastructure.

- Eco-friendly equipment: To check for the impact of eco friendly equipment on the TCO.

- Centralized Department: To find the importance of having a centralized department with an authority and funding to purchase IT (server, storage) equipment as-well-as build data center facilities (power, cooling), with an overall aim of reduced power usage.

- $\quad$ Easily deployable equipment: To study the importance of having easy to deploy facilities (UPS, power, cooling) and IT (servers, storage) equipment.

- Easily upgradable equipment: To study the importance of having easy to upgrade facilities (UPS, power, cooling) and IT (servers, storage) equipment.

The respondents rated these factors on a Likert Type scale of 1 to 5, 1 being "strongly disagreed" and 5 being "strongly agreed". The responses showed agreement (a score of 4 or more) on all most all of the factors, with the "use of eco-friendly equipment" as the top most factors to reduce TCO. This was followed by "having a centralized department", a factor related to having a common view of IT and facility requirements. A centralized department facilitates effective decision-making aiming to reduce power and cooling costs. "Easily upgradable equipment", "continuous trainings and updates" and "using rack mount equipment" came next on the list. The ranked list of these factors is shown in table 1.

Table 1: Top Contributors for reduced TCO

\begin{tabular}{|l|c|}
\hline TCO: Factors & Rank \\
\hline Use of eco-friendly equipment & I \\
\hline Having a centralized department with a common view of IT and facilities & II \\
\hline Easily upgradable equipment & III \\
\hline Trainings and updates & IV \\
\hline Using rack mount equipment & V \\
\hline
\end{tabular}

Journal of Technology Management for Growing Economies, Volume 3, Number 2, October 2012 


\begin{tabular}{|l|c|}
\hline TCO: Factors & Rank \\
\hline Easily deployable equipment & VI \\
\hline SLA with cooling facility providers & VII \\
\hline SLA with power providers & VIII \\
\hline Use of flexible power and cooling infrastructure & IX \\
\hline Use of online serviceable IT equipment & X \\
\hline
\end{tabular}

Towards Cost

Effective Data

Centers

The respondents related TCO to the use of eco-friendly, easily deployable, easily upgradable, online serviceable, flexible rack-mount equipment. It was suggested to have a central department with a view into the IT as well as facilities requirements and design. It was recommended to have appropriate service level agreements with both power as well as cooling providers. It was also recommended to have well-defined Service Level Agreements, even with the Government departments providing raw power to most of these facilities.

Overall mean responses for outsourcing of IT and facilities was the lowest; in fact it was less than 4, pointing it towards disagreement. This may be related to the fact that most of the respondents believe that they should not give the control of their IT equipment to external service providers, primarily because of security reasons. They want to retain the control of their IT equipment. Outsourcing of facilities also scored low, but was still higher than "outsourcing IT" score. Overall, Data Center stakeholders prefer the IT and facilities equipment to be maintained by service providers, but they want to retain the control of these equipment. Table 2 and figure 1 shows descriptive statistics for TCO.

Cronbach alpha for the items measuring TCO was 0.766, indicating consistency and reliability of these items. Interestingly, Cronbach Alpha of the above-mentioned top 10 factors was even higher (0.778), revalidating the reliability of these factors to measure the TCO construct.

While looking at the Spearman's rho, there was minor correlation between most of the factors. "Employee training and updates" was correlated to most of the factors, including "online serviceability", "deployment" and "upgradability". "Trainings and updates" was negatively correlated to "outsourcing", possibly indicating that employee training and updates may not be as important, if we are anyways outsourcing the operations.

"Online serviceability" of equipment was related to "ease to deploy" and "ease to upgrade". "Easily deployable" equipment was correlated to "easily upgradable" equipment, indicating that an easy to install equipment can be easily upgraded, which can further help to reduce operational costs.

Having SLA's with power and facilities providers also showed a strong correlation, indicating the importance and interrelation of power and cooling

Journal of Technology Management for Growing Economies, Volume 3, Number 2, October 2012 
Ahuja, A.

Gautam, V. and the need to have SLAs for both. Having a "Centralized Department", showed minor to strong correlation with all other factors, indicating the interdependence of power, cooling, serviceability and upgradability parameters, and importance of having a single organizational view to reduce overall TCO. Table 3 shows correlation between various factors contributing to Data Center's Total Cost of Ownership (TCO).

Table 2: Descriptive Statistics for TCO

\begin{tabular}{|c|c|c|c|c|c|c|c|c|c|c|c|c|c|}
\hline \multicolumn{14}{|c|}{ Statistics: TCO } \\
\hline & & $\begin{array}{c}\text { Online } \\
\text { Service- } \\
\text { able IT } \\
\text { Equip- } \\
\text { ment }\end{array}$ & $\begin{array}{l}\text { SLA } \\
\text { with } \\
\text { Power } \\
\text { Provid- } \\
\text { ers }\end{array}$ & $\begin{array}{l}\text { SLA } \\
\text { with } \\
\text { Cool- } \\
\text { ing } \\
\text { facility } \\
\text { Provid- } \\
\text { ers }\end{array}$ & $\begin{array}{l}\text { Flex- } \\
\text { ible } \\
\text { Power } \\
\text { and } \\
\text { Cool- } \\
\text { ing }\end{array}$ & $\begin{array}{l}\text { Rack } \\
\text { mount } \\
\text { equip- } \\
\text { ment }\end{array}$ & $\begin{array}{l}\text { Train- } \\
\text { ings } \\
\text { and } \\
\text { Up- } \\
\text { dates }\end{array}$ & $\begin{array}{l}\text { Out- } \\
\text { sourc- } \\
\text { ing } \\
\text { IT }\end{array}$ & $\begin{array}{l}\text { Out- } \\
\text { sourc- } \\
\text { ing } \\
\text { Facili- } \\
\text { ties }\end{array}$ & $\begin{array}{l}\text { Eco } \\
\text { Friend- } \\
\text { ly } \\
\text { Equip- } \\
\text { ment }\end{array}$ & $\begin{array}{c}\text { Cen- } \\
\text { tralized } \\
\text { Depart- } \\
\text { ment }\end{array}$ & $\begin{array}{l}\text { Easily } \\
\text { Deploy- } \\
\text { able } \\
\text { Equip- } \\
\text { mement }\end{array}$ & $\begin{array}{c}\text { Easily } \\
\text { Up- } \\
\text { grad- } \\
\text { able } \\
\text { Equip- } \\
\text { ment }\end{array}$ \\
\hline \multirow[t]{2}{*}{$\mathrm{N}$} & Valid & 145 & 145 & 145 & 145 & 145 & 145 & 145 & 145 & 145 & 145 & 145 & 145 \\
\hline & $\begin{array}{l}\text { Miss- } \\
\text { ing }\end{array}$ & 0 & 0 & 0 & 0 & 0 & 0 & 0 & 0 & 0 & 0 & 0 & 0 \\
\hline \multicolumn{2}{|c|}{ Mean } & 4.0138 & 4.0552 & 4.1448 & 4.0483 & 4.2207 & 4.2414 & 3.3172 & 3.6138 & 4.4759 & 4.3724 & 4.1655 & 4.2621 \\
\hline \multicolumn{2}{|c|}{ Median } & 4 & 4 & 4 & 4 & 4 & 4 & 3 & 4 & 5 & 4 & 4 & 4 \\
\hline \multicolumn{2}{|c|}{ Mode } & 4 & 4 & 4 & 4 & 4 & 4 & 4 & 4 & 5 & 5 & 4 & 4 \\
\hline
\end{tabular}

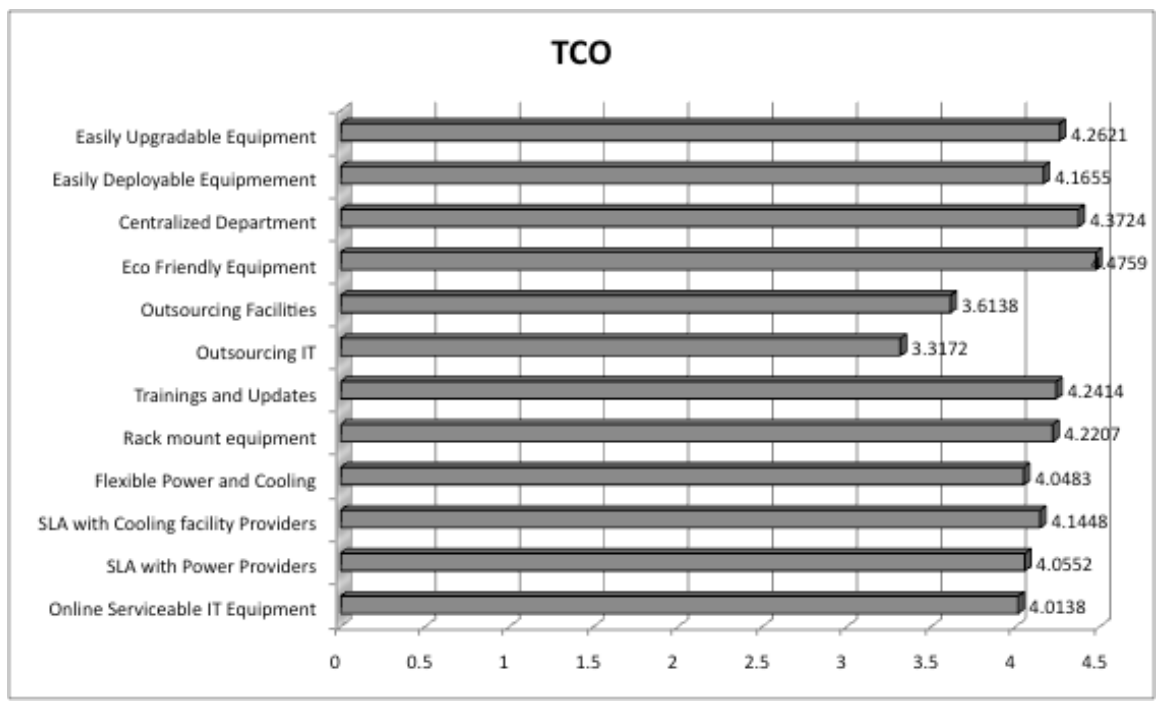

Figure 1: Factors contributing to TCO 
Table 3: Correlation between factors contributing to TCO

\begin{tabular}{|c|c|c|c|c|c|c|c|c|c|c|c|c|c|c|}
\hline \multicolumn{15}{|c|}{ Correlations: TCO } \\
\hline & & & $\begin{array}{l}\text { Online } \\
\text { Ser- } \\
\text { vice- } \\
\text { able IT } \\
\text { Equip- } \\
\text { ment }\end{array}$ & $\begin{array}{l}\text { SLA } \\
\text { with } \\
\text { Power } \\
\text { Provid- } \\
\text { ers }\end{array}$ & $\begin{array}{l}\text { SLA } \\
\text { with } \\
\text { Cooling } \\
\text { facility } \\
\text { Provid- } \\
\text { ers }\end{array}$ & $\begin{array}{l}\text { Flex- } \\
\text { ible } \\
\text { Power } \\
\text { and } \\
\text { Cool- } \\
\text { ing }\end{array}$ & $\begin{array}{l}\text { Rack } \\
\text { mount } \\
\text { equip- } \\
\text { ment }\end{array}$ & $\begin{array}{l}\text { Train- } \\
\text { ings } \\
\text { and } \\
\text { Up- } \\
\text { dates }\end{array}$ & $\begin{array}{l}\text { Out- } \\
\text { sourc- } \\
\text { ing } \\
\text { IT }\end{array}$ & $\begin{array}{l}\text { Out- } \\
\text { sourc- } \\
\text { ing } \\
\text { Facili- } \\
\text { ties }\end{array}$ & $\begin{array}{c}\text { Eco } \\
\text { Friendly } \\
\text { Equip- } \\
\text { ment }\end{array}$ & $\begin{array}{c}\text { Cen- } \\
\text { tralized } \\
\text { Depart- } \\
\text { ment }\end{array}$ & $\begin{array}{c}\text { Easily } \\
\text { Deploy- } \\
\text { able } \\
\text { Equip- } \\
\text { me- } \\
\text { ment }\end{array}$ & $\begin{array}{l}\text { Eas- } \\
\text { ily Up- } \\
\text { grad- } \\
\text { able } \\
\text { Equip- } \\
\text { ment }\end{array}$ \\
\hline \multirow{36}{*}{$\begin{array}{l}\text { Spear- } \\
\text { man's } \\
\text { rho }\end{array}$} & \multirow{3}{*}{$\begin{array}{l}\text { Online Ser- } \\
\text { viceable IT } \\
\text { Equipment }\end{array}$} & $\begin{array}{l}\text { Correlation } \\
\text { Coefficient }\end{array}$ & 1 & 0.146 & 0.15 & .262 & 0.1 & .322 & 0.035 & $.224 "$ & 0.036 & 0.088 & $.306 "$ & .289 \\
\hline & & Sig. (2-tailed) & & 0.08 & 0.072 & 0.001 & 0.231 & 0 & 0.674 & 0.007 & 0.666 & 0.295 & 0 & 0 \\
\hline & & $\mathrm{N}$ & 145 & 145 & 145 & 145 & 145 & 145 & 145 & 145 & 145 & 145 & 145 & 145 \\
\hline & \multirow{3}{*}{$\begin{array}{l}\text { SLA with } \\
\text { Power } \\
\text { Providers }\end{array}$} & $\begin{array}{l}\text { Correlation } \\
\text { Coefficient }\end{array}$ & 0.146 & 1 & $.737^{\prime \prime}$ & $.335^{\prime \prime}$ & $.326^{*}$ & $.503 *$ & 0.062 & 0.082 & .256 & $.377^{*}$ & $.340^{*}$ & .275 \\
\hline & & Sig. (2-tailed) & 0.08 & & 0 & 0 & 0 & 0 & 0.46 & 0.326 & 0.002 & 0 & 0 & 0.001 \\
\hline & & N & 145 & 145 & 145 & 145 & 145 & 145 & 145 & 145 & 145 & 145 & 145 & 145 \\
\hline & \multirow{3}{*}{$\begin{array}{l}\text { SLA with } \\
\text { Cooling facil- } \\
\text { ity Providers }\end{array}$} & $\begin{array}{l}\text { Correlation } \\
\text { Coefficient }\end{array}$ & 0.15 & $.737^{\prime}$ & 1 & $.286^{\prime \prime}$ & $.238^{\prime \prime}$ & $.443^{*}$ & 0.007 & 0.108 & $.201^{\circ}$ & $.349^{*}$ & $.368^{\prime \prime}$ & .243 \\
\hline & & Sig. (2-tailed) & 0.072 & 0 & & 0 & 0.004 & 0 & 0.935 & 0.194 & 0.016 & 0 & 0 & 0.003 \\
\hline & & $\mathrm{N}$ & 145 & 145 & 145 & 145 & 145 & 145 & 145 & 145 & 145 & 145 & 145 & 145 \\
\hline & \multirow{3}{*}{$\begin{array}{l}\text { Flexible } \\
\text { Power and } \\
\text { Cooling }\end{array}$} & $\begin{array}{l}\text { Correlation } \\
\text { Coefficient }\end{array}$ & .262 & $.335^{\prime \prime}$ & $.286^{\prime \prime}$ & 1 & $.240^{\circ}$ & 0.153 & $.342^{\prime \prime}$ & $.251^{\prime \prime}$ & $.297^{\prime \prime}$ & $.455^{*}$ & 0.14 & .186 \\
\hline & & Sig. (2-tailed) & 0.001 & 0 & 0 & & 0.004 & 0.067 & 0 & 0.002 & 0 & 0 & 0.093 & 0.025 \\
\hline & & $\mathrm{N}$ & 145 & 145 & 145 & 145 & 145 & 145 & 145 & 145 & 145 & 145 & 145 & 145 \\
\hline & \multirow[t]{3}{*}{$\begin{array}{l}\text { Rack mount } \\
\text { equipment }\end{array}$} & $\begin{array}{l}\text { Correlation } \\
\text { Coefficient }\end{array}$ & 0.1 & $.326^{\prime \prime}$ & $.238^{*}$ & $.240^{*}$ & 1 & $.300^{\circ}$ & $.164^{\circ}$ & 0.084 & $.284^{*}$ & $.275^{*}$ & 0.139 & 0.118 \\
\hline & & Sig. (2-tailed) & 0.231 & 0 & 0.004 & 0.004 & & 0 & 0.049 & 0.317 & 0.001 & 0.001 & 0.095 & 0.158 \\
\hline & & $\mathrm{N}$ & 145 & 145 & 145 & 145 & 145 & 145 & 145 & 145 & 145 & 145 & 145 & 145 \\
\hline & \multirow[t]{3}{*}{$\begin{array}{l}\text { Trainings and } \\
\text { Updates }\end{array}$} & $\begin{array}{l}\text { Correlation } \\
\text { Coefficient }\end{array}$ & .322 & $.503^{\prime \prime}$ & $.443^{*}$ & 0.153 & $.300^{*}$ & 1 & -0.141 & 0.092 & $.199^{\circ}$ & $.338^{\prime \prime}$ & $.363^{*}$ & .294 \\
\hline & & Sig. (2-tailed) & 0 & 0 & 0 & 0.067 & 0 & & 0.091 & 0.269 & 0.016 & 0 & 0 & 0 \\
\hline & & $\mathrm{N}$ & 145 & 145 & 145 & 145 & 145 & 145 & 145 & 145 & 145 & 145 & 145 & 145 \\
\hline & \multirow[t]{3}{*}{$\begin{array}{l}\text { Outsourc- } \\
\text { ing IT }\end{array}$} & $\begin{array}{l}\text { Correlation } \\
\text { Coefficient }\end{array}$ & 0.035 & 0.062 & 0.007 & $.342 "$ & $.164^{\circ}$ & -0.141 & 1 & $.501^{\prime \prime}$ & 0.099 & $.226^{*}$ & 0.108 & 0.039 \\
\hline & & Sig. (2-tailed) & 0.674 & 0.46 & 0.935 & 0 & 0.049 & 0.091 & . & 0 & 0.237 & 0.006 & 0.195 & 0.64 \\
\hline & & $\mathrm{N}$ & 145 & 145 & 145 & 145 & 145 & 145 & 145 & 145 & 145 & 145 & 145 & 145 \\
\hline & \multirow[t]{3}{*}{$\begin{array}{l}\text { Outsourcing } \\
\text { Facilities }\end{array}$} & $\begin{array}{l}\text { Correlation } \\
\text { Coefficient }\end{array}$ & $.224^{* \prime}$ & 0.082 & 0.108 & $.251^{*}$ & 0.084 & 0.092 & $.501^{\prime \prime}$ & 1 & 0.141 & $.291^{*}$ & 0.153 & 0.006 \\
\hline & & Sig. (2-tailed) & 0.007 & 0.326 & 0.194 & 0.002 & 0.317 & 0.269 & 0 & & 0.09 & 0 & 0.067 & 0.941 \\
\hline & & $\mathrm{N}$ & 145 & 145 & 145 & 145 & 145 & 145 & 145 & 145 & 145 & 145 & 145 & 145 \\
\hline & \multirow[t]{3}{*}{$\begin{array}{l}\text { Eco Friendly } \\
\text { Equipment }\end{array}$} & $\begin{array}{l}\text { Correlation } \\
\text { Coefficient }\end{array}$ & 0.036 & $.256^{\prime \prime}$ & $.201^{\circ}$ & $.297^{\prime \prime}$ & $.284^{\prime \prime}$ & $.199^{\circ}$ & 0.099 & 0.141 & 1 & $.597^{\prime \prime}$ & $.295^{\prime \prime}$ & .280 \\
\hline & & Sig. (2-tailed) & 0.666 & 0.002 & 0.016 & 0 & 0.001 & 0.016 & 0.237 & 0.09 & & 0 & 0 & 0.001 \\
\hline & & $\mathrm{N}$ & 145 & 145 & 145 & 145 & 145 & 145 & 145 & 145 & 145 & 145 & 145 & 145 \\
\hline & \multirow[t]{3}{*}{$\begin{array}{l}\text { Centralized } \\
\text { Department }\end{array}$} & $\begin{array}{l}\text { Correlation } \\
\text { Coefficient }\end{array}$ & 0.088 & $.377^{\prime \prime}$ & $.349^{\prime \prime}$ & $.455^{\prime \prime}$ & $.275^{\circ}$ & $.338 "$ & $.226^{\prime \prime}$ & $.291^{\prime \prime}$ & $.597^{\circ}$ & 1 & $.329^{\prime \prime}$ & .222 \\
\hline & & Sig. (2-tailed) & 0.295 & 0 & 0 & 0 & 0.001 & 0 & 0.006 & 0 & 0 & & 0 & 0.007 \\
\hline & & $\mathrm{N}$ & 145 & 145 & 145 & 145 & 145 & 145 & 145 & 145 & 145 & 145 & 145 & 145 \\
\hline & \multirow{3}{*}{$\begin{array}{l}\text { Easily } \\
\text { Deployable } \\
\text { Equipme- } \\
\text { ment }\end{array}$} & $\begin{array}{l}\text { Correlation } \\
\text { Coefficient }\end{array}$ & $.306^{\prime \prime}$ & $.340^{*}$ & $.368^{*}$ & 0.14 & 0.139 & $.363^{* \prime}$ & 0.108 & 0.153 & $.295^{\prime \prime}$ & $.329^{\prime \prime}$ & 1 & $.633^{\circ}$ \\
\hline & & Sig. (2-tailed) & 0 & 0 & 0 & 0.093 & 0.095 & 0 & 0.195 & 0.067 & 0 & 0 & & 0 \\
\hline & & $\mathrm{N}$ & 145 & 145 & 145 & 145 & 145 & 145 & 145 & 145 & 145 & 145 & 145 & 145 \\
\hline & \multirow{3}{*}{$\begin{array}{l}\text { Easily } \\
\text { Upgradable } \\
\text { Equipment }\end{array}$} & $\begin{array}{l}\text { Correlation } \\
\text { Coefficient }\end{array}$ & $.289^{*}$ & $.275^{*}$ & $.243^{*}$ & $.186^{\circ}$ & 0.118 & $.294^{\prime \prime}$ & 0.039 & 0.006 & $.280^{*}$ & .222 & $.633^{*}$ & 1 \\
\hline & & Sig. (2-tailed) & 0 & 0.001 & 0.003 & 0.025 & 0.158 & 0 & 0.64 & 0.941 & 0.001 & 0.007 & 0 & \\
\hline & & $\mathrm{N}$ & 145 & 145 & 145 & 145 & 145 & 145 & 145 & 145 & 145 & 145 & 145 & 145 \\
\hline
\end{tabular}

Towards Cost

Effective Data

Centers

113

Journal of Technology Management for Growing Economies, Volume 3, Number 2, October 2012 
Ahuja, A.

Gautam, V.

**. Correlation is significant at the 0.01 level (2-tailed).

*. Correlation is significant at the 0.05 level (2-tailed).

\section{COMPARING FACTORS CONTRIBUTING TO TCO - GOVERN- MENT V/S CORPORATE DATA CENTER ORGANIZATIONS}

As a part of this study, inputs were collated, both from the Government and Corporate Data Center stakeholders. The respondents were stakeholders from Government and Corporate Data Center enterprises spread across India. This section compares the responses from these two types of organizations. It is intended to find if the Government and Corporate Data Centers' stakeholders relate lower TCO to similar factors, or if there is a difference in thinking across the two types of organizations.

Since our data did not show normal distribution, non-parametric tests were used to find the differences between the two types of organizations. Non-parametric tests are assumption free tests and work on ranking of the data. Mann-Whiney is one such ranked test, which compares two independent samples. It is an equivalent of independent t-test, for parametric data. MannWhitney test was used to compare responses from the government and corporate organizations.

The statistical output was further analyzed by looking at Asym. Sig (2-tailed) values. A value of less then 0.05 indicated that the "means" of the two organizations i.e. Government $\mathrm{v} / \mathrm{s}$ Corporate were significantly different. The results are discussed in this section.

Table 4 shows Asym. Sig (2-tailed) values and table 5 shows mean rank values for factors contributing to TCO. There is a significant difference in mean ranking of "trainings and updates" and "SLA with cooling facility providers" for Government and Corporate organizations.

Both types of organizations more or less agree to all other factors contributing to reduce TCO. Both Government and Corporate organizations, relate $\mathrm{TCO}$ to the use of online serviceable equipment, flexible power and cooling equipment and having appropriate SLA's with the power providers, this includes having SLA's even with the Government power facility providers. They believe in bringing down the TCO by having eco-friendly, easily deployable, easily upgradable rack mount equipment. Both types of organizations endorse outsourcing, specifically outsourcing of the facility equipment. Both types of organizations recommend a central department with an overall view of cost reduction in power and facilities infrastructure.

Journal of Technology Management for Growing Economies, Volume 3, Number 2, October 2012 
Table 4: Comparative Test Statistics for Factors contributing to TCO

\begin{tabular}{|c|c|c|c|c|c|c|c|c|c|c|c|c|}
\hline \multicolumn{13}{|c|}{ Test Statistics ${ }^{a}$} \\
\hline & $\begin{array}{c}\text { Online } \\
\text { Service- } \\
\text { able IT } \\
\text { Equip- } \\
\text { ment }\end{array}$ & $\begin{array}{l}\text { SLA } \\
\text { with } \\
\text { Power } \\
\text { Pro- } \\
\text { viders }\end{array}$ & $\begin{array}{l}\text { SLA with } \\
\text { Cooling } \\
\text { facility } \\
\text { Provid- } \\
\text { ers }\end{array}$ & $\begin{array}{l}\text { Flex- } \\
\text { ible } \\
\text { Power } \\
\text { and } \\
\text { Cool- } \\
\text { ing }\end{array}$ & $\begin{array}{l}\text { Rack } \\
\text { mount } \\
\text { equip- } \\
\text { ment }\end{array}$ & $\begin{array}{l}\text { Train- } \\
\text { ings } \\
\text { and } \\
\text { Up- } \\
\text { dates }\end{array}$ & $\begin{array}{l}\text { Out- } \\
\text { sourc- } \\
\text { ing } \\
\text { IT }\end{array}$ & $\begin{array}{l}\text { Out- } \\
\text { sourc- } \\
\text { ing } \\
\text { Facili- } \\
\text { ties }\end{array}$ & $\begin{array}{l}\text { Eco } \\
\text { Friend- } \\
\text { ly } \\
\text { Equip- } \\
\text { ment }\end{array}$ & $\begin{array}{c}\text { Cen- } \\
\text { tralized } \\
\text { Depart- } \\
\text { ment }\end{array}$ & $\begin{array}{l}\text { Easily } \\
\text { Deploy- } \\
\text { able } \\
\text { Equip- } \\
\text { mement }\end{array}$ & $\begin{array}{l}\text { Eas- } \\
\text { ily Up- } \\
\text { grad- } \\
\text { able } \\
\text { Equip- } \\
\text { ment }\end{array}$ \\
\hline $\begin{array}{l}\text { Mann- } \\
\text { Whit- } \\
\text { ney U }\end{array}$ & 2514 & 2280 & 2139 & 2179 & 2418.5 & 2000 & 2155 & 2547 & 2322 & 2371.5 & 2219 & 2515 \\
\hline $\begin{array}{l}\text { Wilcoxon } \\
\text { W }\end{array}$ & 5835 & 4360 & 4219 & 5500 & 5739.5 & 4080 & 5476 & 5868 & 4402 & 4451.5 & 4299 & 4595 \\
\hline z & -0.378 & -1.438 & -2.068 & -1.853 & -0.772 & -2.744 & -1.845 & -0.2 & -1.226 & -0.974 & -1.818 & -0.373 \\
\hline $\begin{array}{l}\text { Asymp. } \\
\text { Sig. } \\
\text { (2-tailed) }\end{array}$ & 0.705 & 0.151 & 0.039 & 0.064 & 0.44 & 0.006 & 0.065 & 0.841 & 0.22 & 0.33 & 0.069 & 0.709 \\
\hline
\end{tabular}

Looking at the mean rank values, Government Data Center organizations think that continuous "trainings and updates" can help bring down TCO, whereas Corporate organizations do not relate TCO to "trainings and updates". Government organizations do not favor outsourcing of IT equipment and prefer to own their IT assets, this is primarily for security reasons and also due to Government policies. Both Government and Corporate organizations think that outsourcing the facilities infrastructure, which includes both power and cooling and also having a centralized department to manage IT as well as the facilities, can reduce TCO.

Table 5: Government v/s Corporate - Mean ranking of Factors contributing to TCO

\begin{tabular}{|l|l|c|c|c|}
\hline & Type Of Organization & N & $\begin{array}{c}\text { Mean } \\
\text { Rank }\end{array}$ & $\begin{array}{c}\text { Sum of } \\
\text { Ranks }\end{array}$ \\
\hline Online Serviceable IT Equipment & Government & 81 & 72.04 & 5835 \\
\hline & Corporate & 64 & 74.22 & 4750 \\
\hline & Total & 145 & & \\
\hline SLA with Power Providers & Government & 81 & 76.85 & 6225 \\
\hline & Corporate & 64 & 68.13 & 4360 \\
\hline & Total & 145 & & \\
\hline SLA with Cooling facility Providers & Government & 81 & 78.59 & 6366 \\
\hline & Corporate & 64 & 65.92 & 4219 \\
\hline & Total & 145 & & \\
\hline Flexible Power and Cooling & Government & 81 & 67.9 & 5500 \\
\hline & Corporate & 64 & 79.45 & 5085 \\
\hline & Total & 145 & & \\
\hline
\end{tabular}

Journal of Technology Management for Growing Economies, Volume 3, Number 2, October 2012
Towards Cost

Effective Data

Centers 
Ahuja, A.

Gautam, V.

\begin{tabular}{|c|c|c|c|c|}
\hline & Type of Organization & $\mathbf{N}$ & $\begin{array}{l}\text { Mean } \\
\text { Rank }\end{array}$ & $\begin{array}{l}\text { Sum of } \\
\text { Ranks }\end{array}$ \\
\hline \multirow[t]{3}{*}{ Rack mount equipment } & Government & 81 & 70.86 & 5739.5 \\
\hline & Corporate & 64 & 75.71 & 4845.5 \\
\hline & Total & 145 & & \\
\hline \multirow[t]{3}{*}{ Trainings and Updates } & Government & 81 & 80.31 & 6505 \\
\hline & Corporate & 64 & 63.75 & 4080 \\
\hline & Total & 145 & & \\
\hline \multirow[t]{3}{*}{ Outsourcing IT } & Government & 81 & 67.6 & 5476 \\
\hline & Corporate & 64 & 79.83 & 5109 \\
\hline & Total & 145 & & \\
\hline \multirow[t]{3}{*}{ Outsourcing Facilities } & Government & 81 & 72.44 & 5868 \\
\hline & Corporate & 64 & 73.7 & 4717 \\
\hline & Total & 145 & & \\
\hline \multirow[t]{3}{*}{ Eco Friendly Equipment } & Government & 81 & 76.33 & 6183 \\
\hline & Corporate & 64 & 68.78 & 4402 \\
\hline & Total & 145 & & \\
\hline \multirow[t]{3}{*}{ Centralized Department } & Government & 81 & 75.72 & 6133.5 \\
\hline & Corporate & 64 & 69.55 & 4451.5 \\
\hline & Total & 145 & & \\
\hline \multirow[t]{3}{*}{ Easily Deployable Equipment } & Government & 81 & 77.6 & 6286 \\
\hline & Corporate & 64 & 67.17 & 4299 \\
\hline & Total & 145 & & \\
\hline \multirow[t]{3}{*}{ Easily Upgradable Equipment } & Government & 81 & 73.95 & 5990 \\
\hline & Corporate & 64 & 71.8 & 4595 \\
\hline & Total & 145 & & \\
\hline
\end{tabular}

\section{CONCLUSION}

Total Cost of Ownership (TCO) is a key measure of Data Centers' Organizational Effectiveness. A Lower TCO leads to cost effective Data Centers. Various factors contributing to "reduced TCO" have been discussed and recommended in this paper.

These factors include - use of eco-friendly equipment, having a centralized department with a common view of IT as well as facilities infrastructure, easily upgradable and easily deployable equipment, continuous trainings and updates, use of rack-mount equipment, having appropriate Service Level Agreements (SLS's) with the power and cooling infrastructure providers, use of flexible power and cooling infrastructure and use of online serviceable IT equipment.

Data Center organizations can use these recommendations to bring down the Total Cost of Ownership, further leading overall Organizational Effectiveness. 
It was also inferred that both Government as well as Corporate Data Center organizations relate lower TCO as a critical measure for cost effective Data Centers. Both the organizations related lower TCO to similar factors.
Towards Cost

Effective Data

Centers

\section{REFERENCES}

Ahuja, A. (2006) 'State Data Center Dynamic Design and Components' In Bhattacharya, J. (ed.), Technology in Government, New Delhi, GIFT Publishing, pp. 46 - 57.

Beer, M., Eisenstat, R.A. and Biggadike, E.R. (1995) 'Strategic Change: A New Dimension to HRM' In Ferris, G. R., Rosen, S. D. and Barnum, D. T. (eds.), The Handbook of Human Resource Management, Cambridge Massachusetts, Blackwell Publishers, pp. 120.

Cameron, K.S. (1986) 'Effectiveness as Paradox: consensus and conflicts in conception of Organizational Effectiveness', Management Science, 32:5, 539 - 553. http://dx.doi. org/10.1287/mnsc.32.5.539.

Gautam, V. and Batra, S.K. (2007) Organization Development Systems, New Delhi, Concept Publishing.

Gopalakrishnan, P. (1992) Cost Reduction Handbook, Bombay, Jaico Publishing House.

Lewin, A.Y. and Minton, J.W. (1986) 'Determining Organizational Effectiveness: Another look, and an agenda for research', Management Science, 32:5, 514-539. http://dx.doi. org/10.1287/mnsc.32.5.514.

Patterson, M.K., Costello, D.G., Grimm, P.F. and Loeffler, M.(2007). Data Center TCO: a comparison of high density and low-density spaces [White Paper]. Retrieved from www. intel.com/technology/eep/datacenter.pdf

Powell, W.W. (1987) ' Hybrid Organizational arrangements', California Management Review, 30 (fall), 67-87.

Rasmussen, N. (2005). Determining Total Cost of Ownership for Data Center and Network Room Infrastructure [White Paper]. Retrieved from www.apcmedia.com/salestools/ CMRP-5T9PQG_R4_EN.pdf

Thorelli, H.B. (1986) 'Networks between markets and hierarchies', Strategic Management Journal, 7, pp. 37-51. http://dx.doi.org/10.1002/smj.4250070105.

Williamson, O.E. (1991) 'Comparative economic organizations, the analysis of discrete structural alternatives', Administrative Science Quarterly, 36, pp. 269 - 296. http://dx.doi. org/10.2307/2393356.

Wilson, R.M.S. (1983) Cost Control handbook (second edition), Hants, England, Gower Publishing Company Limited.

Ajay Ahuja, is Director Solution Consulting, Sun Microsystems India Pvt. Ltd., New Delhi, India. Email: ajayahuja68@gmail.com.

Vinayshil Gautam, is Professor, Department of Management Studies, Indian Institute of Technology, New Delhi, India. Email: gautamvinay @ hotmail.com. 